\title{
Substance as the Main Structural Component in the Development of Human Free Will in Spinoza's Philosophy
}

\author{
Mohammad Malla ${ }^{1,2, *}$ \\ ${ }^{1}$ Department of History of Philosophy, Faculty of Humanities and Social Sciences, Peoples' Friendship \\ University of Russia (RUDN University), Moscow, Russia \\ ${ }^{2}$ Ugarit Ras Shamra, Latakia, Syria \\ *Corresponding author. Email: kar.malla1994@gmail.com
}

\begin{abstract}
The article concerns the problem of substance and its development in the philosophical system of Spinoza. The article deals with the dialectic of the existence of free will in the religious philosophy of Spinoza. The author analyzes the nature of substance and its influence on the development of the free will concept, and also concerns the idea of the unity of substance as a community of the generative nature and the generated nature. The central position of Spinoza's philosophical system is the identity of God and Nature (pantheism). Spinoza's most famous ethical postulate is "Freedom is a conscious necessity." In the philosophy of Spinoza, the problem of free will is related to the problem of substance. The relation between free will and substance is Spinoza's main method in his study of human existence. In the article it would be pointed that Spinoza considered substance to be God, and substance consists attributes, thus, attribute is one of the forms of substance. Then the important idea is that one of the most important characteristics of substance is thinking and extension. Thinking is an attribute of God, in other words, God is a thinking thing.
\end{abstract}

Keywords: Ethics, God, Substance, Nature, Will, Freedom, Soul.

\section{INTRODUCTION}

Benedict (Baruch) Spinoza (1634-1677) - one of the most interesting philosophers in the history of philosophy, he was also called the reformer of the new philosophy. One of the most important indicators of the depth and vitality of Spinoza's philosophical teaching is its influence on the thinkers of subsequent generations, and even more so of centuries. Spinoza devoted his whole life to the development of his teaching. And it is not surprising that even now there is a great interest for his philosophy.

The development of the teachings of Benedict Spinoza began and continued for several years in a religious Jewish school. The study was based not only on the study of religious texts, but also on the study of philosophers. His teaching was based on pantheism, in which there is a fairly consistent identification of God and nature. The philosophical teaching of the Dutch philosopher can be considered as the main stage in the transition from pantheism to materialism.

The philosophical system of Spinoza has no sharp jumps, since the philosopher was quite consistent with his beliefs. A characteristic feature of the philosopher is a method of clear reasoning and well-structured and formed evidence. [1]

In order to build a reliable knowledge of true philosophy, scholastic attitudes and concepts were revised. Philosophers turned to the comprehension and generalization of the methods of mathematics, because they saw in its truths the manifestation of the "natural light of the human mind, which, by its own efforts, without the help of any authorities and even without the help of the supernatural "revelation of God" is able to penetrate into any mystery and comprehend any truth.

The purpose of this work is a comprehensive study of the problem of free will in the philosophy of Spinoza. 
Therefore, in this article it will be presented the main positions of his thought regarding concepts of substance and free will, as well as considered the features of Spinoza's pantheism.

\section{UNITY OF MODES AND ATTRIBUTES IN THE CONCEPT OF SUBSTANCE}

At the heart of the philosopher's doctrine of nature is the doctrine of substance, which Spinoza equated with God, that is, with nature. Spinoza believed that substance is something that can exist by itself and represent itself through itself. Based on this teaching, we can conclude that substance consists of attributes. For example, God has an unlimited number of attributes, but our knowledge can identify only two attributes from the entire variety.

One of them is the corporeal substance, in other words, it is an attribute of extension. Spinoza said that extension has a physical meaning and can be called the negation of emptiness. But according to Spinoza's views substance cannot be reduced only to extended matter, since it also contains thought as an attribute. Spinoza believed that substance had two attributes, which are extension and thinking. They are synthesized with God.

Spinoza denied the existence of God from the point of view of his personality. Substance, that is God, is infinite and can manifest its essence in an unlimited number of forms and images, which we call attributes. Thus, attributes are forms of manifestation of substance. Spinoza argued that even though there are an infinite number of attributes, we can distinguish only two - thinking and extension.

The attribute "extension" is one of the properties of the substance, since in the absence of this attribute, it is impossible to imagine any goal that has a completion. Extension is the defining feature of the body. It is itself indivisible, since divisibility is a kind of appearance of the final thing. Spinoza like Descartes denied emptiness believing that it does not exist.

Modes cannot exist without a substance with its attributes, and a person would not be able to perceive it. In the structure of Spinoza there are three types of modes: infinite, finite, and complex modes. God as substance is the cause of himself and the cause of infinite attributes and modes.
Drawing a conclusion, we can say that Spinoza in his philosophy stepped over the dualistic model that was inherent in Descartes. If in Descartes the attributes of extension and thought can exist in themselves as substances, in Spinoza they are a single whole. [2]

Spinoza considered every definition to be a negation, but substance cannot be defined in any way, what means there is no negation.

Spinoza's pantheism is an important concept that completed his teaching about substance as a single organism. Based on all the conclusions that we have given above, we can assume that according to Spinoza God is a substance that has infinite attributes and the world is made up of modes, both finite and infinite. But both categories do not have the right to exist without each other, since there are cause-and-effect relationships in regards on the nature of God. Nothing happens occasionally and the world is an important consequence of God.

\section{THE CONTROVERSY OF THE EXISTENCE OF FREE WILL IN SPINOZA}

Spinoza believed that man's ideas about his own will were false. He believed that regarding a person, it is impossible to say that he has free will, which acts separately from the soul. Spinoza thought that the influence of bodies on the soul, and not vice versa, is much stronger. The philosopher generally denied the will, if it is considered as an independent faculty in the human soul. He believed that the will consists of a number of human desires, which are caused by certain reasons. That is why Spinoza concluded that will is reason.

The knowledge of freedom can be realized by three methods - sensory, rational and intuitive.

- The sensory mode of cognition means the cognition of things in terms of their physical properties.

- The rational way of cognition is the cognition of freedom with the help of the understanding, when a person comprehends things in a holistic connection with each other through reasoning and logical comprehension. A rational way of cognition allows a person to achieve active and meaningful freedom.

- The intuitive way is the highest level of knowledge of freedom, in which a person realizes his divine destiny. 
Intuition enables the cognitive love of God: "All modes of thinking have God as their cause, in so far as he is a thinking thing, and not in so far as he is expressed by any other attribute." [3]

Freedom according to Spinoza is the possession of one's emotions, which can only be achieved by studying and knowing them. Accordingly, in order to gain freedom, it is necessary to know yourself. By Spinoza freedom was opposed not to necessity, but to violence and coercion.

The freedom that is achieved by working in the mind is contradictory. The first step on the path to freedom, as the philosopher believed, is when a person puts all his ideas in order, connecting them with things. When there is a correspondence of ideas and order in nature, then a person has the opportunity to bring his body in accordance with the order of his ideas. It is in this way that a person can achieve mastery over his own affects. This is exactly what Spinoza taught about freedom.

Free will is not an illusion, it is the result of something that has been suppressed by most people who have realized their actions, but have not delved deeply into the causes that based them. [4]

The ego creates the idea of "free will", which in its essence is nothing but an illusion. Spinoza believes that to understand free will in this way is wrong. From his point of view, it is an illusion. Under the mask of this illusion there are always some unconscious reasons. In order to understand free will properly, it is necessary to understand and identify the hidden, unconscious reasons for which certain actions are performed. This definition of free will as an illusion led to Spinoza's accusation of extreme fatalism. In this case, there is a logical error, since the accusers equate freedom in general with freedom of will.

\section{SUBSTANCE AS A FUNDAMENTAL SYNTHESIS OF GOD AND NATURE}

It is necessary to consider the concept of nature. Nature in the philosophy of Spinoza is divided into two kinds: generative and generated. The generative personifies the cause, the generated is the effect. Accordingly, nature has two sides and each has the right to exist.

- The generative nature is God, since he can exist through himself and he is the cause of his existence, manifesting in attributes.
- The generated nature is the world resulting from the necessity and importance of the nature of God himself and his attributes.

Thus, the pantheism of the philosopher is founded on the fact that the manifestation of God can be seen in everything.

When Kuno Fischer in his classic monograph devoted to B. Spinoza touches on the question of the amazing purposefulness of the thinker in defending monistic and deterministic ideas, he with a certain degree of slyness contrasts his teleological understanding of the historical process with the causal ideas of Spinoza himself, arguing that only a person of special abilities and a special life path could hold such views and create such a teaching and the appearance of a person of this type must correspond to a certain final cause. [5]

Fischer believes that Spinoza's point of view on the nature of substance, and, consequently, on the entire universe, is unique in its kind, excluding all others and rejected by others, contradicting the philosophical views of other thinkers and opposing both consistent idealism and consistent materialism.

As for Spinoza's monistic system, Descartes criticized it because it had no definite status in substance. On the one hand, only the substance, which is infinite, has a real being, namely, God. All created substances are in close interaction from God.

There is a section on the one substance in the first part of the treatise Ethics, which is called $O n$ God. The philosopher believed that only one substance is true, its attributes are thinking, nature and prevalence. Spinoza believed that there are no substances other than God. By substance, he meant something that exists in itself, that is something that does not need to be represented with the help of another thing, from which the formation came. In doctrine of Spinoza, God and substance were a single concept, since he believed that God does not rise above nature, he does not influence God, since God is inside.

Spinoza identified several important properties of substance:

- Substance exists because the idea is always clear and distinct.

- The substance has a property that we call independence, that is it does not depend on another being.

- Substance is the first cause in itself, since nothing exists outside of substance. 
- The substance is inherent in infinity in the relations of time and space, because the substance is not included in the flow of time, it finds the self within it.

- Substance is eternal. In itself, eternity is unchangeable, it is timeless. Thus, Spinoza believed that God is either a substance or a nature that is the cause of itself.

Spinoza's teaching is monistic in nature, in which we are talking only about one substance, which is divine, namely, it is everything. Substance for Spinoza is the essence in which all necessary existence is contained, substance is the cause of itself by origin. Since the substance is the cause of itself, Spinoza also distinguished the other properties of the substance. They are: an eternity in time and infinity in space.

Thus, substance is what can be called nature or God. Spinoza in this matter departed from religious views.

The psychophysical problem of the interaction of the physical and spiritual in man, which occupied a huge place in anthropology of Descartes, was solved by Spinoza through monistic parallelism. Sensuously abstract knowledge creates in the soul of man the emotions and passions that bind all his actions and make him the plaything of fate. Usually, people are convinced that they are endowed with free will and their actions are carried out by them completely freely. Spinoza said that the doctrine of substance is the doctrine of man, his moral perception of life, which is endowed with wisdom. Freedom, according to Spinoza, is a necessity that is already known. It is important, because a person should strive for freedom. If we accept freedom of will as an illusion that originates from inadequate abstract ideas, then real freedom, true freedom, can only be when a person reaches the level of adequate ideas and comprehends the unity of his freedom and necessity.

\section{DIALECTICAL RELATIONSHIP BETWEEN THE CONCEPTS OF DETERMINISM AND FREE WILL}

The concept of determinism as an unambiguous conditionality of all phenomena by their causes is determined from the premises of the unity of substance. Everything in the world has its cause, and only substance has a cause in itself. [6]

According to Spinoza, there is a certain contradiction in the very essence of freedom, which is achieved through the activity of human consciousness. The contradiction is that such freedom is both passive and active.

As Spinoza says, "we are excited in various ways by external causes and are agitated like the waves of the sea, driven by opposite winds, not knowing about our outcome and our fate" [7]

At the same time, the philosopher specifically stipulates that complete mastery over oneself is impossible, and therefore absolute freedom is also impossible. The reason for this excitement is the emotions that the philosopher calls affects. According to Spinoza's definition, affects directly affect the state of the body, make it more capable or, conversely, less capable of action, and not only the affects themselves, but also the ideas of the affects. [8]

A person is inherent in thinking, that is, the ability to build his own activities in accordance with the shape and position of other bodies in the external world, but not only with the properties of his own body. As Spinoza puts it: "A free thing is a thing that exists only by the necessity of its own nature and is determined to act only by itself." [9]

Thus, the knowledge of the individual's own human emotions is not only possible, but also necessary. At the same time, everyone has the ability for such knowledge.

Each person can understand their affects and their impact on their soul and see the causes and consequences of their actions with all clarity:

"The soul, whether it has ideas clear and distinct or vague, strives to remain in its existence for an indefinite time, and is conscious of this striving." [10]

As the philosopher states: "Affect can only be destroyed or 'tamed' by a stronger affect." [11]

Thus, "it is necessary to know both the capacity and the incapacity of our nature, in order to be able to determine what the mind is capable of in controlling the affects and what it is not" [12]

Pleasure and freedom are inextricably linked in Spinoza's philosophy. Absolute pleasure in Spinoza is equal to absolute freedom, and both the first and the second are essentially cognitive love for truth, that is for God.

Thus, free will in Spinoza's view is deterministic. Free will can be only apparent, since the human mind is limited and unable to comprehend the totality of the reasons that cause certain desires, and after them - and actions. It 
turns out that any human actions in the world are caused by one or another necessity.

However, while denying free will, Spinoza constantly speaks about the freedom of man as a whole. In the fifth part of Ethics, as an introduction, he promises to show the road that leads to freedom, to prove that the human mind is able to overcome his emotions and achieve not only freedom, but also bliss. Spinoza clarifies: "By God I mean a being absolutely infinite, that is a substance consisting of infinitely many attributes, each of which expresses an eternal and infinite essence." [13]

Therefore, freedom within the framework of Substance is directly linked to necessity, that is freedom and necessity exist in dialectical unity. Intuition as a complete knowledge gives us an understanding of the essence of particular things and leads to the absolute truth.

Summing up, we can draw the following conclusions:

- Freedom and the need for substance are combined into one whole;

- God (Nature) is endowed with complete freedom, but he acts within the framework of strict necessity;

- Modes (manifestations of substance individual things) do not have freedom at all and are completely subordinate to necessity;

- Mode-a person differs from all other modes by the presence of thinking, and, therefore, strives for freedom, but, at the same time, being a mode, is not free and is in the "grip" of necessity;

- Wishing to be free in the soul, a person often floats along with the current of necessity, cannot cope with this current and is forced to put up with necessity (it is a "spiritual automaton", in the words of Spinoza);

- The path to freedom is finding the conditions under which external necessity turns into internal necessity;

- Identified the attributes of the substance in the number of two-extension and thinking;

- Freedom is a recognized necessity.

\section{CONCLUSION}

Analyzing the theoretical material that is available about the philosophy of Spinoza, we can say that the philosopher had a monism that is pantheistic in nature, since the philosopher identified God with nature.

Very important in the works of Spinoza was his station regarding substance concept, in this its merit is necessary.

Spinoza developed a theory of substance that considered the whole essence of being. The main aspects of this teaching are followed. There is simply no difference between God, as the supreme substance, and the others that he created; there is a place for the existence of only one substance, in which everything that exists around is enclosed. It is this substance that contains both nature and God himself; The unity between nature and God, who is outside of nature, God, as it were, rises above nature, and at the same time is within it; only nature and God together have the ability to create something, Nature and God are that, what can create the created world, that is, individual things that have the name of modes.

As for the ethics of Spinoza, the key role was played by the problems of determinism, that is the conditionality of everything in nature, and the relationship between freedom and necessity. After conducting research in this area, Spinoza summarized that freedom and the need for substance merge into a single whole. God, who is also nature, has complete freedom, but he can only act within the framework of necessity.

The path to freedom is those conditions that help to transform an external necessity into an internal one, since freedom is a recognized necessity. To achieve greater freedom, a person needs to:

- Free yourself from the affects, that is sorrows, joys, desires and the others.

- If possible and as much as possible to know the substance of nature -God.

Affects, as Spinoza believed, have a sufficiently strong influence on a person, since they influence freedom, subjugating a person and forcing him to act only when necessary.

In connection with the latter, Spinoza's motto became popular: "Not to laugh, not to cry, not to curse, but to understand."

\section{AUTHORS' CONTRIBUTIONS}

This paper is independently completed by Mohammad Malla. 


\section{REFERENCES}

[1] B. Spinoza, Ethics, Selected works: in 2 t. m.: Gospolitizdat, 1957, pp. 345-389.

[2] K. Fischer, R. Descartes, his Life, Writings and Teachings, Edited by N. N. Polilov, - St. Petersburg: D. E. Zhukovsky, 1906, p. 460.

[3] B. Spinoza, Favorites, Medley Publishing House, Minsk, 1999, p. 126.

[4] J.W. V. Goethe, Publishing house "Fiction", M. t 3, 1976, p. 569.

[5] K. Fischer, History of the New Philosophy, Benedict Spinoza, M: ACT: Transitkniga, 2005, p.557.

[6] A. Schweitzer, Culture and ethics, Progress Publishing House, M. 1973, p. 51.

[7] The Bible, The New Testament, The Gospel of John, M.: Krutitskoe podvorye, 2016, p. 476.

[8] B. Spinoza, Theological and political treatise, Moscow: Sotsekgiz, 1935, pp. 417-471.

[9] S. B. Rocinsky, B. Spinoza's Pantheism and V. Solovyov's Unity: Lines of Convergence and Divergence//The Wise and eternally young Spinoza, M: RAGS Publishing House, 1999, p. 713.

[10] B. Spinoza, Ethics, Selected works: in 2 t. m.: Gospolitizdat, 1957, p. 321.

[11] K. Fischer, History of the New Philosophy, Benedict Spinoza, M: ACT: Transitkniga, 2005, p.147.

[12] Ibid., p. 191.

[13] Ibid., p. 415. 